Горик О. В., доктор технічних наук,

Ковальчук С. Б., асистент,

Яхін С. В., кандидат технічних наук,

Ландар А. А., кандидат технічних наук

Полтавська державна аграрна академія

\title{
АНАЛІТИЧНО-ЕКСПЕРИМЕНТАЛЬНЕ ВСТАНОВЛЕННЯ РЕСУРСУ НЕСУЧОЇ ЗДАТНОСТІ ЕЛЕМЕНТІВ КАРКАСУ СТАДІОНУ «ВОРСКЛА» іМ. ОЛЕКСІЯ БУТОВСЬКОГО (М. ПОЛТАВА) ПОВІДОМЛЕННЯ 1. ВИЗНАЧЕННЯ ТЕХНІЧНОГО СТАНУ
}

Рецензент - доктор технічних наук, професор А. А. Смердов

Подано результати дослідження технічного стану конструкиій трибунної споруди стадіону «Ворскла» імені Олексія Бутовського в м. Полтава. На основі натурних вимірювань прогинів похилих ригелів поперечних рам каркасу (за максимального заповнення трибун глядачами) розроблено модель просторової роботи інженерних конструкцій споруди, шуо дало можливість прогнозувати експлуатаційний ресурс. Виявлено пріоритетні причини $i$ наслідкові дефекти й міру їх впливу на технічний стан будівельних конструкцій. Розроблено рекомендації щуодо надійної й безпечної експлуатації стадіону «Ворскла» м. Полтава.

Ключові слова: трибунна споруда, технічний стан, корозія, дефект, експлуатаиійний ресурс, елементи каркасу.

Постановка проблеми. Відповідно до чинного законодавства увесь існуючий будівельний фонд потребує періодичного обстеження, оцінювання технічного стану й паспортизації будівель і споруд. Об'єкти з масовим перебуванням людей (зали для глядачів, спортивні арени, торгові манежі) знаходяться під особливо пильним постійним спостереженням і створенням умов безпечної та надійної їх експлуатації. У Полтаві таким об'єктом є головна спортивна арена обласного центру - стадіон «Ворскла» імені Олексія Бутовського. Спортивний комплекс стадіону об'єднує трибунну споруду (4 трибуни) у вигляді замкнутої чаші, що вміщує 24850 місць для глядачів, спортивну арену 3 футбольним полем, трьома легкоатлетичними секторами й біговими доріжками, освітлювальні металеві вишки та відкриті спортивні площадки, розташовані за межами трибун. Стадіон $\epsilon$ тренувальною та ігровою базою футбольного клубу «Ворскла», а також ареною спортивних змагань різних рівнів i проведення масових міських заходів. Простір під трибунами споруди використовується під адмі- ністративно-господарські та побутові приміщення і приміщення для занять спортом.

Колективом авторів і субпідрядних наукових організацій вперше виконано повний комплекс робіт $з$ оцінки технічного стану та рекомендацій щодо безпечної й надійної експлуатації спортивної споруди. Звіт включає: 6 томів, 17 книг, 20 папок, 7050 фотографій. У даній статті подані основні підходи і нові моделі встановлення резерву несучої здатності елементів каркасу стадіону.

Експлуатаційна надійність споруди стадіону «Ворскла» визначається несучою здатністю залізобетонних елементів каркасу, тобто їх міцністю, просторовою і лінійною жорсткістю та стійкістю. Останній конструктивний параметр не викликає сумнівів, зважаючи на достатні розміри поперечних перерізів стиснутих елементів і їх розрахункову довжину. Просторова жорсткість також забезпечена передусім стійкою формою споруди. Крім цього у поперечному напрямку жорсткість рам забезпечується защемленням колон у фундаментах, а в поздовжньому напрямку жорсткість споруди забезпечена дисками покриттів (перекриттів), залізобетонними розпірками та металевими хрестовими в'язями між колонами.

Проте міцність і жорсткість основних елементів потребують глибшого аналізу, адже дефекти й руйнування, що виникли 3 часом, і невдалі проектні рішення суттєво впливають на ці конструктивні параметри каркасу та окремих його елементів. Споруда експлуатується під відкритим небом. Ступінчата конструкція покрівлі трибун, на якій влаштовано безліч вузлів кріплення сидінь, та інтенсивний потік глядачів не дали змоги досягти належної гідроізоляції підтрибунного простору (приміщень і конструкцій), хоча для вирішення цієї проблеми був розроблений спеціальний проект реконструкції. Дощові й талі води продовжують просочуватись (а місця- 
ми й протікати) в підтрибунний простір. Зволожені й насичені вологою залізобетонні конструкції руйнуються, особливо взимку - за різкої зміни температури. Деякі залізобетонні елементи мають руйнування тіла на глибину до 50 мм із відшаруванням чи випаданням захисного шару бетону та значною корозією арматури. Тому експлуатаційна надійність споруди стадіону, зважаючи на його технічний стан і рівень наслідків можливої аварії, потребує глибокого наукового дослідження.

Аналіз останніх досліджень i публікацій, у яких започатковано розв'язання проблеми. Зважаючи на вимоги до об'єктів із масовим перебуванням людей та ускладнені умови експлуатації, починаючи з 1988 року, періодично проводились обстеження технічного стану конструкцій стадіону. Зокрема, були розроблені й запроваджені системи підсилення верхніх похилих ригелів рам Східної трибуни влаштуванням зовнішніх тяжів у нижній зоні ригелів із пристроєм контролю напружень [1-4], вибіркове підсилення колон влаштуванням металевої обойми 3 наступним торкретуванням $[1,5]$, а також стягування цегляних стін коментаторських приміщень металевими тяжами [6] та інше. Ці обстеження й конструктивні рішення носили локальний характер і виконувалися під той чи інший захід або до початку нового футбольного сезону. При цьому видавались короткострокові дозволи на експлуатацію стадіону та рекомендації стосовно подальшої експлуатації переважно протягом одного року.

Мета та завдання досліджень: дати оцінку дійсному технічному стану будівельних конструкцій, визначити відповідність до проектних рішень і експлуатаційних вимог, що пред'являються до спортивних споруд, визначити резерв несучої здатності та встановити можливість надійного використання обстеженої споруди за цільовим призначенням 3 урахуванням наявних дефектів $\mathrm{i}$ пошкоджень або часткової чи повної їх ліквідації, розробити висновки про можливість подальшої експлуатації стадіону «Ворскла» імені Олексія Бутовського в м. Полтава.

Матеріали і методи досліджень. Об'єкт дослідження - композитні залізобетонні елементи просторового каркасу трибунної споруди стадіону. Результати дослідження базувалися на натурних обстеженнях і лабораторних випробовуваннях, а також на архівних та аналітичних розрахункових даних. Використане обладнання та прилади для польових, камеральних робіт і лабораторних випробувань пройшли атестацію відповідно до метрологічних вимог. У ході виконання робіт дотримані вимоги «Нормативних документів 3 питань обстежень, паспортизації, безпечної та надійної експлуатації виробничих будівель та споруд», затверджених спільним наказом Державного комітету будівництва, архітектури та житлової політики України і Держкомнаглядохоронпраці України від 27.11.1997 p. №32/288.

Результати дослідження. Стадіон «Ворскла» - це споруда, котра за конструктивною системою відноситься до каркасних. Споруда об'єднує чотири об'ємно-конструктивні складові, названі відповідно до орієнтації за частинами світу: Східна, Південна, Західна та Північна трибуни. В основу споруди покладено систему поперечних та радіальних збірних залізобетонних одно-, двох- і триярусних рам із похилими верхніми консольними ригелями, на яких влаштовані місця для глядачів. Рами західної трибуни та рами в зонах сполучення трибун мають різні геометричні й конструктивні параметри, відповідно до просторової форми споруди. Сусідні рами сполучені між собою залізобетонними монолітними і збірними дисками та окремими елементами-ригелями. На між'ярусних дисках (перекриттях) розташовані приміщення різного призначення.

ПРОСТОРОВА МОДЕЛЬ СТАДІОНУ. ДЛЯ утворення об'ємно конструктивного змісту стадіону, формування вихідних даних для розрахунку напружено-деформованого стану конструкцій каркасу з урахуванням їх просторової роботи, візуалізації стадіону та створення фактичної цифрової моделі споруди була створена графічно-просторова модель (тривимірне описання об'єкту). Графічно-просторова модель базувалася на використанні сучасного спеціалізованого програмного продукту, в якому реалізовано концепцію параметричного моделювання. Параметрична модель споруди стадіону чи окремої трибуни інтегрувала власне тривимірну модель (геометрію та дані) і модель поведінки елементів (систему управління змінами).

На основі архівних проектних даних та натурних обстежень було створено основні конструктивні елементи каркасу стадіону (колони, ригелі, плити), після чого виконано «зборку» елементів 3 урахуванням взаємного їх розташування, визначеного цифровими просторовими координатами. Такий процес створення моделі нагадує будівельно-монтажні роботи при спорудженні об'єкту.

Для отримання інформації про геометрію спо- 
руди на час обстеження, виявлення міри впливу несприятливих факторів на просторове положення (переміщення) елементів конструкцій, перевірки адекватності розрахункової моделі на основі порівняння результатів натурних вимірів iз розрахунковими даними (Повідомлення 2) та моніторингу за станом основних несучих елементів стадіону створена також просторовоцифрова модель споруди.

ДЕФЕКТИ ТА ПОШКОДЖЕННЯ. Невдалим проектним рішенням $є$ влаштування ненадійного зовнішнього гідроізоляційного асфальтобетонного килиму на поверхні трибун, що стало пріоритетною причиною погіршення технічного стану конструкцій та зниження їх експлуатаційної надійності. Спроба ліквідувати цей дефект пізніше призвела ще до одного помилкового конструктивного рішення - влаштування нового неефективного гідроізоляційного килиму із склотканини на бітумній мастиці та поверх нього захис- ного бетонного шару товщиною близько 70 мм.

Цей головний конструктивний недолік, що призводить до зволоження й насичення вологою залізобетонних конструкцій, $\epsilon$ першопричиною виникнення і розвитку багатьох інших дефектів, а саме: руйнування поверхонь, оголення арматури з різною мірою корозії, виникнення поверхневих і наскрізних тріщин, корозія металевих елементів, візуально видимі прогини та ін.

Усі дефекти й невдалі технічні рішення поділяються на причинні (рівень 1, див. рис.) і наслідкові (рівень 2). Пріоритетним (причинним) дефектом і пріоритетним невдалим технічним рішенням стали: ненадійна гідроізоляція споруди і збільшення навантаження на несучі елементи за рахунок влаштування нової конструкції покрівлі трибун. Інші виявлені дефекти елементів каркасу, окрім механічних руйнувань, є наслідковими (рівень 2).

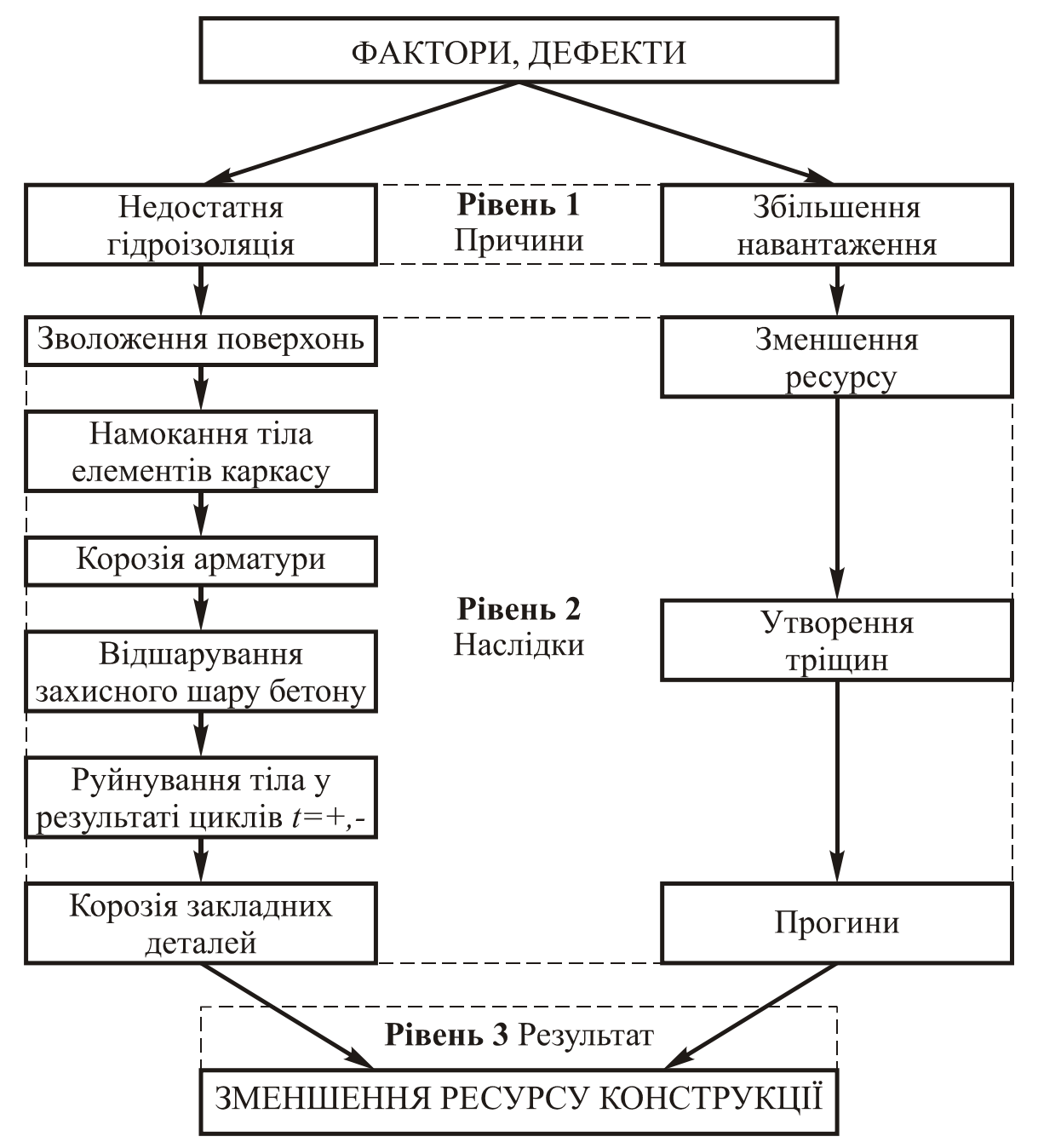

Рис. Схема залежності дефектів від причин ӥх утворення 
На схемі (див. рис.) залежності процесу утворення дефектів від першопричин наочно подано причинний зв'язок між дефектами і несучою здатністю елементів конструкцій. Усунення того чи іншого наслідкового дефекту не призупиняє повністю процес руйнування. Тому у ході розробки рекомендацій щодо подальшої експлуатації основна увага зверталася на першочергове усунення причинних дефектів (рівень 1, див. рис.), а вже потім - на ремонт конструкцій, тобто усунення наслідкових дефектів (рівень 2). Врахувавши міру впливу дефектів першого та другого рівнів на несучу здатність елементів конструкцій та ступінь їх відновлення в результаті ремонту (усунення дефектів), прогнозувався експлуатаційний резерв надійної роботи каркасу та його окремих елементів.

Серед наслідкових дефектів визначальним за результатами технічної діагностики $\epsilon$ корозія робочої арматури залізобетонних конструкцій, процес якої без додаткових спеціальних заходів уже не призупинити, навіть ліквідувавши причинні дефекти. Тому одним із головних завдань став пошук шляхів значного сповільнення динаміки ії розвитку.

Уже понад 30 років залізобетонні елементи каркасу стадіону експлуатуються під відкритим небом і знаходяться під впливом опадів, які містять хлористі сполуки. Ці розчинні сполуки, потрапивши у тріщини залізобетонних конструкцій, викликають активну корозію арматури і бетону.

Досліджувалися такі види електрохімічної корозії арматури в бетоні: загальна корозія - це електрохімічне руйнування металу арматури, викликане оточуючим бетонним середовищем, та корозія, викликана дією макрогальванічних пар - це електрохімічне руйнування металу в результаті різниці потенціалів на різних ділянках поверхні арматури.

Специфічною особливістю електрохімічної корозії є поділ взаємодії металу з середовищем на два процеси: анодний - перехід металу в розчин із можливим наступним утворенням малорозчинних продуктів корозії; катодний - приєднання вільних електронів певним деполяризатором. Протікання електрохімічної корозії залізобетонних елементів стадіону характеризується локалізацією катодного й анодного процесу на різних ділянках.

Інтенсивність корозії арматурної сталі визначалася співвідношенням швидкостей різних реакцій, що протікають на анодних і катодних ділянках. Фактори, які знижують швидкість ка- тодної реакції (порівняно з анодною), призводять до руйнування сталевої арматури.

Умовою виникнення макрогальванічних пар $\epsilon$ неоднорідність середовища (бетону), що оточує арматуру; це має місце при нерівномірному зволоженні елементів конструкцій каркасу. В цьому випадку виникають гальванічні пари зі значними катодними і малими анодними ділянками, що викликає значну щільність струму гальванічної пари на анодній ділянці, і як наслідок, інтенсивну корозію арматури та закладних деталей. На ділянках, де зберігся сухий і щільний бетон захисного шару, утворивши досить однорідне середовище, що прилягає до арматури, різко знизило протікання корозійних процесів металевих фаз залізобетону.

За основний показник корозії арматури в бетоні елементів каркасу стадіону приймався комплексний показник, який визначався після виміру основних електричних параметрів - стаціонарного потенціалу арматури та електричного опору бетону захисного шару ригелів трибун. Різні значення стаціонарного потенціалу вздовж арматурного стержня вказували на можливу корозію арматури.

Цей показник визначався за формулою:

$$
\Delta C_{i}=\frac{U_{i-1}-U_{i}}{R_{i}+R_{i-1}}-\frac{U_{i+1}-U_{i}}{R_{i}+R_{i+1}},
$$

де: $U_{i-1}, U_{i}, U_{i+1}$ - заміряні вздовж арматурного стержня стаціонарні потенціали в точках зліва $\left(U_{i-1}\right)$ та справа $\left(U_{i+1}\right)$, а також у точці між ними $\left(\Delta C_{i}\right)$, для якої визначався комплексний показник $\Delta C_{i}$;

$R_{i-1}, R_{i}, R_{i+1}$ - заміряний вздовж арматурного стержня опір бетону захисного шару в точках зліва $\left(R_{i-1}\right)$ та справа $\left(R_{i+1}\right)$, а також у точці між ними $\left(R_{i}\right)$, для якої визначався комплексний показник $\left(\Delta C_{i}\right)$.

Додатне значення показника $\left(\Delta C_{i}\right)$ вказувало на анодну ділянку, а від'ємне - на катодну ділянку в даному місці поверхні арматурного стержня. Чим більше додатне значення комплексного показника, тим інтенсивніший процес корозії арматури в даному місці. Більшість елементів каркасу стадіону відповідали додатнім значенням комплексного показника.

Тому виникла нагальна необхідність у теоре- 
тичному прогнозуванні ресурсу міцності, пов'язаної з розвитком процесу корозії в арматуpi залізобетонних несучих елементів, передусім верхніх похилих ригелів рам. Загальний експлуатаційний часовий ресурс елементів стадіону, внаслідок розвитку корозії, визначався за ресурсом міцності ригелів згідно з методикою професора В. О. Бондаря.

Питома швидкість зменшення перерізу арматури в тріщині визначали за формулою

$$
r=\frac{\ln D_{1}-\ln D_{2}}{T},
$$

де $D_{1}, D_{2}$ - початковий діаметр арматури i діаметр після впливу корозії протягом певного часу $T$.

Залишковий часовий ресурс за несучою здатністю ригелів трибунної споруди стадіону, знаючи показник $r$, визначали за формулою

$$
T=\frac{\ln m-\ln z_{0}}{r},
$$

де: $z_{0}=z_{2} / z_{1}-$ відношення плеча внутрішньої пари сил у перерізі ригеля на час дослідження до плеча на час руйнування (розрахункові величини); $m=R_{s} / \sigma_{s}-$ відношення нормативного опору арматури ( $\left.R_{s}=280 M \Pi a\right)$ до експлуатаційного на час дослідження $\left(\sigma_{s}=250 M \Pi a\right)$.

Дослідження свідчать про те, що корозія арматури і бетону несучих елементів конструкцій каркасу стадіону виявилася визначальним критерієм оцінки технічного стану й експлуатаційного ресурсу споруди в часі.

Особливі умови корозії арматури залізобетонних елементів вимагають запровадження нових, нетрадиційних способів їх захисту. Окрім ліквідації дефекту першого рівня, у даному випадку запропоновано електрохімічний метод захисту арматури від корозії, - простий у виконанні й експлуатації. Сутність даного методу полягає у наступному.

\section{БІБЛІОГРАФІЯ}

1. Технічний звіт по обстеженню будівельних конструкцій стадіону «Ворскла» (108001-01-ОД.АС) // Харківський «ПРОМСТРОЙНИИПРОЕКТ». 1992.

2. Висновок про технічний стан та експлуатаційну надійність залізобетонних ригелів і їх сталевих тяжів-затяжок підсилення Східної трибуни стадіону «Ворскла» у м. Полтава. // ТОВ «СПЕЦБУДРЕКОНСТРУКЦІЯ - 95». - 2002.
Процес корозії призупиняється за рахунок зміни напряму струму в арматурі від зовнішнього джерела струму. На поверхні елементів запропоновано розташувати анод (електропровідну фарбу 3 графітовим наповненням, лінійні дротяні аноди та інші), а роль катода, у даному випадку, виконуватиме арматура елементів, яка підлягає захисту й яка замикається в електричний ланцюг 3 анодом. Постійний електричний струм підводиться до аноду, а потім через бетон - до арматури. Арматура буде під захистом при досягненні найменшого значення потенціалу 0,75B по відношенню до сульфатного електроду порівняння.

Прогнозування експлуатаційного ресурсу на основі результатів дослідження технічного стану остову спортивної трибуни стадіону буде висвітлено у Повідомленні 2.

Висновки. Відповідно до ознак, наведених у [7], та висновків у [8], технічний стан споруди стадіону «Ворскла» імені Олексія Бутовського в місті Полтава задовільний (категорія II). Першочергового термінового усунення дефектів або повної заміни потребує гідроізоляційна конструкція покрівлі трибун, на якій розташовані місця для сидіння глядачів (1-й рівень дефектів, див. рис.).

Інші дефекти й пошкодження конструкцій трибун є наслідковими (2-й рівень дефектів). Ці дефекти й пошкодження, основними причинами виникнення яких $€$ локальне зволоження окремих залізобетонних елементів дощовими та талими водами (особливо при змінному заморожуванні й відтаванні) визначають динаміку зміни технічного стану несучих залізобетонних конструкцій каркасу і конструкцій огородження стадіону.

Корозія арматури і бетону несучих елементів конструкцій виявилася визначальним наслідковим критерієм оцінки технічного стану й експлуатаційного часового ресурсу споруди. Запропонований електрохімічний метод захисту арматури від корозії - ефективний і простий.

3. Звіти про обстеження будівельних конструкцій Східної трибуни стадіону «Ворскла» (№ 2114/01-31), (№ 2114/01-31), (№ 2423/05), (2696/07) // Полтавський національний технічний університет імені Юрія Кондратюка. - 2003, 2004, 2005, 2007.

4. Звіт про технічний стан залізобетонних конструкцій Східної трибуни стадіону «Ворскла» у м. Полтава // Багатогалузевий науково-технічний 
центр «Віра». - 2008. - $136 \mathrm{c}$.

5. Звіт про науково-дослідну роботу «Обстеження технічного стану будівельних конструкцій стадіону «Ворскла» (№ 2062/01) // Полтавський державний технічний університет імені Юрія Кондратюка. -2001.

6. «Реконструкция стадіону «Ворскла» в г. Полтава» (шифр 108001-01) // Харківський «ПРОМСТРОЙНИИПРОЕКТ». - 1993.

7. Нормативні документи з питань обстежень, паспортизації, безпечної та надійної експлуатації виробничих будівель і споруд // Наказ Державного комітету будівництва, архітектури та житлової політики України та Держнаглядохоронпраці України. - 27.11.1997. - № 32/288.

8. Звіт про результати технічного обстеження та про технічний стан будівельних конструкцій стадіону «Ворскла» імені Олексія Бутовського в м. Полтава (1/1-09) // Багатогалузевий науковотехнічний центр «Віра». - 2008. - Том 1. - 150 с. 